\title{
Student Enrolment and Output Effects in Poland: 2SLS and VAR Estimates
}

\author{
Joanna Żyra
}

\section{A B S T R A C T}

Objective: The purpose of this article is to investigate the direct effects of student enrolment on industrial production and GDP while controlling other growth determinants such as physical capital investments and employment.

Research Design \& Methods: Educational effects on output, i.e. industrial production and gross domestic product (GDP), are estimated by means of Two-Stage Least Squares (2SLS) model, vector error-correction autoregression (VAR/VEC) model, and with the application of annual data sample for the period of 1992-2017.

Findings: The study proves that there is a significant correlation between the number of students and output in Poland, especially with respect to the industrial sector. Regardless of estimators used, higher output is related to a decline in student enrolment in a long period of time. Investments in physical capital are an important factor responsible for both higher output and stronger student enrolment. Employment appears to influence neither GDP growth nor student enrolment. However, employment negatively impacts changes in industrial production.

Implications \& Recommendations: In the presence of an inverse correlation between economic growth and the number of students, the author argues in favour of discreet government policies aimed at boosting student enrolment in alignment with the pattern of investment activities.

Contribution \& Value Added: The article contributes to a better understanding of two-way causation between student enrolment and economic growth in Poland, with clear guidelines for educational policies aimed at a better match with demand for high-skilled labour in industry.

\section{Article type: research article}

Keywords: higher education; economic growth; 2SLS; VAR; Poland

JEL codes: $\quad$ C32, E24, 123

Received: 25 September $2019 \quad$ Revised: 28 October $2019 \quad$ Accepted: 7 November 2019

\section{Suggested citation:}

Żyra, J. (2019). Student Enrolment and Output Effects in Poland: 2SLS and VAR Estimates. Entrepreneurial Business and Economics Review, 7(4), 131-146. https://doi.org/10.15678/EBER.2019.070408 


\section{INTRODUCTION}

The steep increase in the number of university students in Poland from ten to above 50 in the population of 1000 inhabitants in the 1990s and mid-2000s may reflect a new reality of transformation, stronger influence of international markets, or modern approaches to economic development, as earlier experienced by industrialised countries in 1970-1980 (Schofer \& Meyer, 2005). However, the higher education system has been diminishing over the last decade, as the number of students has fallen by a third. Among European countries, only Italy and Switzerland have fewer students per 1000 inhabitants (Abankina \& Filatova, 2015). Such a situation can be caused by an overburdening of the labour market with high-skilled workers. Furthermore, the accumulation of human capital is of concern, especially in the context of the so-called middle-income trap that Poland is approaching (Zaremba, 2018).

Theoretically, higher education contributes to economic growth both directly - as implied by endogenous growth models (Lucas, 1988; Romer, 1990) - or indirectly, as it creates better opportunities for applying new technologies (Nelson \& Phelps, 1966). Moreover, economic growth can be stimulated by positive externalities, such as technology and productivity spillovers in the labour market (Hermannsson, Lisenkova, Lecca, McGregor, \& Kim, 2017).

Numerous empirical studies analysed the causal correlation between higher education and economic growth only to produce conflicting results. Likewise, it is unclear what factors contribute to the worldwide expansion of higher education. Earlier studies show that economic development positively influences enrolment, but the effect is not significant if scholars control secondary enrolments (Schofer \& Meyer, 2005). A study in the expansion of higher education in five countries - Germany, Italy, France, the USA, and Japan - in 1870-1985 does not support the human capital theory while favouring the 'status competition,' which implies an particularly fast increase in the number of students during economic recession (Windolf, 1992). Regardless of possible explanations, there is evidence that the correlation between investments in education and economic growth results from reverse causality (Bils \& Klenow, 2000).

The aim of this article is to estimate direct effects of student enrolment on industrial production and GDP, while controlling other growth determinants, such as physical capital investments, employment, and the likely reverse causality between the number of students and growth. Despite thorough discussion of the topic - especially in the context of the higher education reform in Poland - for example by Marklund et al. (2017) or Kot and Slusarczyk (2014), empirical studies of educational effects on output (GDP and industrial production) are still in short supply. Compared to earlier studies by Shevchuk and Zyra (2012), Nowak (2016), Simionescu, Lazányi, Sopková, Dobeš, and Balcerzak (2017), or Gradzewicz, Growiec, Kolasa, Postek, and Strzelecki (2018), our present study is distinguished by the use of both Two-Stage Least Squares (2SLS) and vector error-correction autoregression (VAR/VEC) models in a comparative context in order to empirically estimate the two-way causality between economic growth and the number of students in Poland. Our key results show that there is a positive role of higher education in the economic growth in Poland, while there is a negative lagged link between economic growth and the number of students. The rest of the article is 
organized as follows. Section 2 reviews relevant literature. Section 3 presents description of the data and methodology applied. In Section 4, the empirical results are discussed. The final Section 5 provides conclusions.

\section{LITERATURE REVIEW}

Most empirical studies indicate that higher education is one of the components of human capital that leads to economic growth, even though particular mechanisms may be considerably heterogeneous.

A recent study of growth determinants in the euro-area countries for the period of 1950-2011 by Barcenilla-Visús and López-Pueyo (2018) provides reliable evidence for significant direct and indirect effects of human capital on the process of total factor productivity (TFP) growth. The number of unskilled workers boosts imitation-led activities in the EU countries while highly qualified employees are essential for growth through innovation. Such findings seem to contradict arguments proposed by Benhabib and Spiegel (1994), who state that positive human capital growth effects are much stronger in the richest countries, while the effect of catching up dominates in poorer countries. Similar conclusions appear in several other studies, for example, Petrakis and Stamatakis (2002) or Vandenbussche, Aghion, and Meghir (2006). However, Krueger and Lindahl (2001) claim that education is statistically significant and positively related to growth only for countries with low levels of education. Based on a dataset of European regions for 2001-2010, Cuaresma, Doppelhofer, Huber, and Pitibauer (2018) recently come to the conclusion that both human capital and income convergence act as important factors and stimuli of income growth not only today but also for the decades to come. With reference to the experience of several CEE countries, some argue that only the quality of higher education and innovation activities can be considered as incentives of economic growth (Fotea \& Guțu, 2016).

Although the majority of empirical studies favours positive correlation between education and economic growth (Mankiw, Romer, \& Weil, 1992; Barro \& Sala-i-Martin, 1995; Cuaresma et al., 2018; Barcenilla-Visús \& López-Pueyo, 2018), many studies indicate the insignificant effect of higher education on GDP growth (Benhabib \& Spiegel, 1994; Islam, 1995; Pritchett, 2001; Yardimcioğlu, Gürdal, \& Itundemir, 2014; Bulman, Eden, \& Nguen, 2017), or even a negative effect (Lenkei, 2017). For example, countryspecific studies indicate that higher education contributes to economic growth in Argentina and Brazil (Boldin, Morote, \& McMullenm, 1996), Greece (Pegkas \& Tsamadias, 2014), Sweden (Obradović \& Lojanica, 2016), and the United Kingdom (Madsen \& Martin, 2017). No positive effects of higher education growth appear for Greece (Asteriou \& Agiomirgianakis, 2001) and Portugal (Pereira \& Aubyn, 2009).

Eckstein, Sarid, and Tamir (2017) state that education influences economic growth in levels, in accordance with the Nelson-Phelps approach. Hanushek and Woessmann (2008) argue that the cognitive skills of a population - rather than mere school accomplishment - strongly relate to individual earnings and economic growth. Delgado, Henderson, and Parmeter (2014) obtained similar results. Although in South Africa higher education does not have any impact on economic growth, it is not the case with doctoral studies (Bhorat, Cassim, \& Tseng, 2016). Besides choosing an educational variable, empirical results depend on such heterogeneous factors as data sample, types of data (cross-section, panel or 
time series), which specify the statistical model or even publishing bias (for example, Benos \& Zotou, 2014). Nevertheless, there are numerous studies that attempt to explain the negative correlation between higher education and economic growth.

Scholars found for a sample of 14 Asian countries in 1960-2013 that tertiary education has a negative long-run impact due to the low proportion of people educated at the tertiary level. What may explain this result are insufficient labour market opportunities for highly educated workers and the brain drain phenomenon (Lenkei 2017). Another reason may be related to the long-term nature of education in general and higher education in particular. As established by Marconi (2018), the positive relationship between education and economic growth is noticed with respect to individuals 45-64 years old, while the education level of younger cohorts (ages 25-44) is not significantly related to economic growth.

The role of higher education is particularly important in countries with the middleincome trap. There are 12 East Asian countries in which the stock of human capital plays an important role in economic growth, even after controlling for convergence factors (Otsuka, Higuchi, \& Sonobe, 2017). As education became a significant factor in the period of 1985-2010, many argued that technology could be easily imitated with low GDP per capita. However, when the technological gap narrows, the countries that invest in human capital have the ability to use the existing technology gap. In the case of high technology availability, even the population without higher education can imitate advanced technology. Although Bulman et al. (2017) do not perceive a clear connection between education, innovation, and growth in middle- and low-income countries, they still confirm that the growth in middle-income countries is positively related to industrialization, along with openness and equality.

It is likely that the effectiveness of higher education is dependent upon specialization in high-tech and knowledge-intensive activities. With respect to the OECD countries, Teixeira, and Queiros (2016) indicate that a lack of industrial structures to enable proper integration of highly educated individuals into the production system leads to disappointing economic returns on education. An important role of industry in education is supported by the experience of Asian middle-income countries (Su \& Yao, 2016). A two-way causality between education and economic growth is confirmed empirically for 25 OECD countries in 1990-2008 (Yardimcioğlu et al., 2014) and for 86 countries in 1960-1990 (Podrecca \& Carmeci, 2002).

Among Central and Eastern European (CEE) countries, positive effects of higher education appear in the Czech Republic and Romania (Dragoescu, 2015; Oancea, Pospíšil, \& Drăgoescu, 2017). The same lack of favourable mutually reinforcing causality that runs from economic growth to higher education can be seen in Sweden (Obradović \& Lojanica, 2016), Japan, the UK, France (De Meulemeester \& Rochat, 1995), and Greece (Pegkas \& Tsamadias, 2014). Although the majority of empirical research conducted on a number of students or with respect to the years of study supports positive higher education growth effects, the expenditure on education generates economic growth only in the Czech Republic, without similar growth effects in the Slovak Republic, Hungary, Poland, and Romania (Simionescu et al., 2017).

Earlier estimates for Poland in 1988-2009 suggest that the number of students (graduates) has positive growth effects, in line with the Nelson-Phelps approach (Shevchuk \& 
Zyra, 2012). Gradzewicz et al. (2016) indicate a positive link between the share of persons with tertiary educational attainment and Poland's economic growth. Another study for Poland relates the positive growth effects of higher education to the development of entrepreneurship among young people (Nowak, 2016).

Our main hypothesis is that an increase in the number of students contributes to output growth, while there is a higher demand for education in line with output gains. Moreover, we cannot rule out that both relationships have a specific intertemporal pattern, with substantial differences between short- and long-term effects.

\section{MATERIAL AND METHODS}

Our empirical study utilizes annual time series for 1992-2017. Besides the number of students per 1000 of the population as the educational variable (Figure 1), I employed several other macroeconomic variables (Figure 2). The study obtained data for real GDP, industrial production, and employment from the IMF International Financial Statistics online database. Except for employment, all other variables reveal a similar upward trend throughout the period under consideration, with no sign of any structural breaks. The industry gains are well below those of the GDP. Employment has been recovering ever since a decline in 1998-2003, with a local stagnation in 2010-2013. Investments in physical capital seem to follow the pattern of employment since the beginning of the last decade.

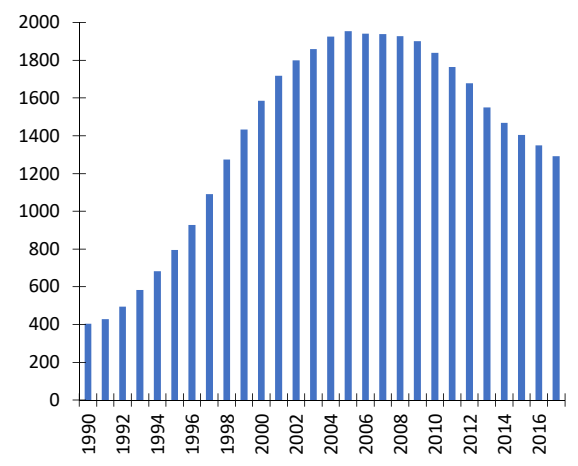

a) total number (in thousands)

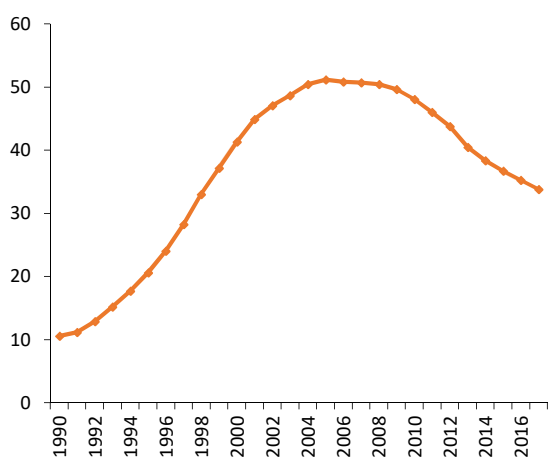

b) per population of 1000

Figure 1. The number of students in Poland in 1990-2017

Source: own elaboration based on Statistics Poland data retrieved from https://bdl.stat.gov.pl/BDL/dane/podgrup/temat on September 5, 2019.

Table 1 summarizes descriptive statistics of the data series, with a split into two samples. As the year 2000 marks a symbolic end of the transition process combined with a turnaround in employment, it is interesting to compare empirical estimates for longer and shorter data samples. Furthermore, the comparison serves the purpose of checking the robustness of our results. The comparison of the two samples indicates that the standard deviation is lower for most of the variables in the shorter sample of 2000-2016. Natural logs of these variables are used in all empirical work. 


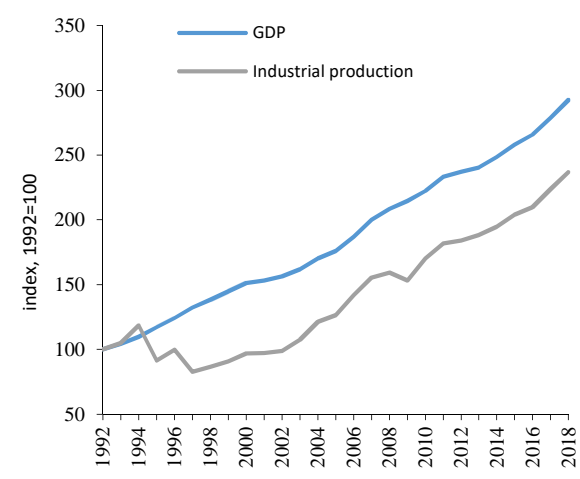

a) output

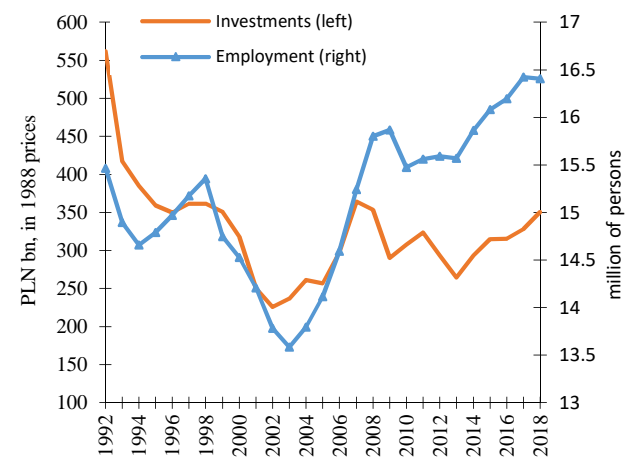

b) investments and employment

Figure 2. Selected macroeconomic indicators for Poland in 1992-2018

Source: own elaboration based on IMF International Financial Statistics data retrieved from http://data.imf.org/?sk=4C514D48-B6BA-49ED-8AB9-52B0C1A0179B\&sld=1390030341854 on September 5, 2019.

Table 1. Descriptive statistics of macroeconomic indicators for Poland in 1992-2017

\begin{tabular}{|l|r|r|r|r|r|}
\hline \multicolumn{1}{|c|}{ Variable } & Average & Median & $\begin{array}{c}\text { Max. } \\
\text { value }\end{array}$ & $\begin{array}{c}\text { Min. } \\
\text { value }\end{array}$ & $\begin{array}{c}\text { Std. } \\
\text { deviation }\end{array}$ \\
\hline The number of students per 1000 of population, $S_{t}$ & 38.5 & 41.4 & 51.2 & 12.9 & 12.20 \\
\hline Industrial production (index, 2010=100), IND $D_{t}$ & 74.4 & 71.7 & 124.2 & 30.6 & 29.70 \\
\hline Gross domestic product (index, 2010=100), $Y_{t}$ & 102.9 & 93.6 & 156.4 & 51.6 & 31.50 \\
\hline $\begin{array}{l}\text { Real investment expenditure (bn of zlotys, } \\
\text { in 1988 prices), INV } t\end{array}$ & 241.9 & 241.2 & 340.7 & 100.2 & 76.20 \\
\hline Employment (in millions), LABOURt & 15.0 & 15.2 & 16.2 & 13.6 & 0.74 \\
\hline
\end{tabular}

Source: own elaboration based on the Statistics Poland data retrieved from https://stat.gov.pl/; IMF International Financial Statistics retrieved from http://data.imf.org/ on September 5, 2019.

In order to verify the order of variables integration, I applied Augmented DickeyFuller (ADF) and Phillips-Perron (PP) statistics. The appropriate lags for the tests were selected with the Akaike Information Criterion (AIC) and Schwartz Bayesian Criterion $(\mathrm{SBC})$. Both unit root tests show that the logarithms of the series (in lowercase) are integrated of order one, while their first differences are stationary (Table 2). The evidence of I(1) is somewhat weaker for $s_{t}$ and inv $t$ (ADF), but in other cases, the series seems to have a unit root for both samples.

Table 3 presents the results of the Granger test, which demonstrate that there runs a bidirectional causality from the number of students to economic growth and vice versa, though with a different time pattern. Today it looks like student enrolment is influenced by either industrial production or GDP. Past values of $s_{t}$ impact both ind $d_{t}$ and $y_{t}$, with the effect on the latter looking more persistently. 
Table 2. The ADF and Phillips-Perron tests of selected macroeconomic indicators for Poland in 1992-2017

\begin{tabular}{|l|c|c|c|c|}
\hline \multirow{2}{*}{ Variable } & \multicolumn{2}{|c|}{ ADF } & \multicolumn{2}{c|}{ Phillips-Perron } \\
\cline { 2 - 5 } & Levels & First differences & Levels & First differences \\
\hline$S_{t}$ & $-2.13\left(0.03^{* *}\right)$ & $-2.18\left(0.03^{* *}\right)$ & $0.95(0.90)$ & $-1.95\left(0.05^{* *}\right)$ \\
\hline ind $_{t}$ & $-1.59(0.76)$ & $-4.32\left(0.01^{* *}\right)$ & $-1.34(0.85)$ & $-5.06\left(0.0^{* * *}\right)$ \\
\hline$y_{t}$ & $-3.19(0.11)$ & $-3.83\left(0.03^{* *}\right)$ & $-1.97(0.58)$ & $-4.14\left(0.01^{* *}\right)$ \\
\hline inv $_{t}$ & $-1.09(0.59)$ & $-4.85\left(0.0^{* *}\right)$ & $-2.26(0.18)$ & $-3.08\left(0.04^{* *}\right)$ \\
\hline labour $_{t}$ & $-1.64(0.44)$ & $-2.75\left(0.0^{* * *}\right)$ & $0.30(0.76)$ & $-2.82\left(0.0^{* * *}\right)$ \\
\hline
\end{tabular}

Note: all variables are in logarithms.

Source: own elaboration based on Statistics Poland data retrieved from https://stat.gov.pl/ on September 5,

2019); IMF International Financial Statistics data retrieved from http://data.imf.org/ on September 5, 2019.

Table 3. Granger test for causality between student enrolment and output in Poland in 1992-2017

\begin{tabular}{|l|c|c|c|c|}
\hline \multirow{2}{*}{ Lags } & \multicolumn{4}{|c|}{ Null hypothesis } \\
\cline { 2 - 5 } & $\boldsymbol{s}_{\boldsymbol{t}}$ does not cause ind $_{\boldsymbol{t}}$ & ind $_{\boldsymbol{t}}$ does not cause $\boldsymbol{s}_{\boldsymbol{t}}$ & $\boldsymbol{s}_{\boldsymbol{t}}$ does not cause $\boldsymbol{y}_{\boldsymbol{t}}$ & $\boldsymbol{y}_{\boldsymbol{t}}$ does not cause $\boldsymbol{s}_{\boldsymbol{t}}$ \\
\hline 1 & $3.358\left(0.08^{*}\right)$ & $141.73\left(0.0^{* * *}\right)$ & $0.087(0.77)$ & $59.721\left(0.0^{* * *}\right)$ \\
\hline 2 & $8.540\left(0.0^{* * *}\right)$ & $1.599(0.22)$ & $0.845(0.44)$ & $1.510(0.44)$ \\
\hline 3 & $1.310(0.30)$ & $2.300(0.11)$ & $0.747(0.54)$ & $4.077\left(0.02^{* *}\right)$ \\
\hline
\end{tabular}

Note: $* * * * *$, and $*$ mean statistical significance at the level of $1 \%, 5 \%$, and $10 \%$, respectively;

p-values are in brackets.

Source: own calculations in EViews 10 (2017).

As there is bidirectional causality between the educational and output variables, I employed both 2SLS and VAR methods. They allowed me to assess the robustness of the estimates, but also identify possible differences. The VAR model is especially useful for describing the dynamic behaviour of economic time series and forecasting. However, the 2SLS estimates appeared as more stable with respect to the length of the sample and the choice of endogenous variables.

My 2SLS two-equations model is as follows (in first differences):

$$
\begin{gathered}
\Delta y_{t}=\alpha_{0}+\alpha_{i} \Delta y_{t-i}+\beta_{i} \Delta s_{t-i}+\delta_{i} s_{t-i}+\gamma_{1} \Delta \text { labor }_{t}+\gamma_{2} \Delta i n v_{t-j}+\varepsilon_{t} \\
\Delta s_{t}=\emptyset_{0}+\emptyset_{1} \Delta s_{t}+\theta_{i} \Delta y_{t-i}+\rho \Delta i n v_{t}+\epsilon_{t}
\end{gathered}
$$

where:

$y_{t}$ - output (industrial production or GDP);

$s_{t}$ - the number of students per 1000 of population;

labor $_{t}$ - employment (a million people);

$i n v_{t}$ - investments (bn of zlotys, in 1988 prices);

$\varepsilon_{t}, \epsilon_{t}$ - stochastic factors;

$\Delta$ - first difference operator.

Equation (1) assumes that output growth is influenced by both human and physical capital, but also employment. Following Krueger and Lindahl (2000), educational variable enters growth regression simultaneously in both levels and first differences. Such a specification allows for the identification of two mechanisms of higher education growth effects, i.e. accumulation of knowledge (the Phelps-Nelson approach) and investments in human capital (the neoclassical model). In case of the former, higher education influences 
economic growth in levels, while the latter impacts growth effects in first differences. Equation (2) implies that changes in the number of students are influenced separately by output and investments. The relationship between the number of students and output reflects the demand for labour and wage expectations. In the presence of control for the general economic situation by the output variable, the effects of investments in physical capital are supposed to reflect the likely impact of innovations.

Although VAR analysis rarely appears in the empirical literature on education and growth (Pereira \& Aubyn, 2009), it can nevertheless provide additional insight into the relationship between both variables, especially in the presence of a two-way causality between them. As the series are integrated of order one As the series are nonstationary in levels and stationary in first differences, i.e. I(1), it is necessary to test for a cointegration relationship between the number of students and both industrial production and GDP. As Table 4 shows, both trace and eigenvalue statistics indicate the presence of one cointegration equation between educational variable and industrial production/GDP.

Table 4. The results of the Johansen cointegration test for student enrolment and output in Poland in 1992-2017

\begin{tabular}{|c|c|c|c|c|}
\hline $\begin{array}{c}\text { Null } \\
\text { hypothesis }\end{array}$ & \multicolumn{2}{|c|}{ Specification with ind $_{\boldsymbol{t}}$ and $\boldsymbol{s}_{\boldsymbol{t}}$} & \multicolumn{2}{c|}{ Specification with $\boldsymbol{y}_{\boldsymbol{t}}$ and $\boldsymbol{s}_{\boldsymbol{t}}$} \\
\hline $\mathrm{H}_{0}: r=r_{0}$ & Trace statistic & Max Eigen statistic & Trace statistic & Max Eigen statistic \\
\hline$r=0$ & $18.26\left(0.0^{* * *}\right)$ & $15.82\left(0.00^{* * *}\right)$ & $14.75\left(0.02^{* *}\right)$ & $12.24\left(0.03^{* *}\right)$ \\
\hline$r=1$ & $2.39(0.14)$ & $2.39(0.14)$ & $2.51(0.14)$ & $2.51(0.14)$ \\
\hline
\end{tabular}

Note: as indicated by the specification tests (normality and autocorrelation of errors), specification with no intercept or trend is used for testing cointegration between ind $t_{t}$ and $s_{t}$, while specification with intercept and linear trend is used in cointegration test with $y_{t}$ and $s_{t}$.

Source: own calculations in EViews 10 (2017).

Since the series of the number of students and output are integrated with rank $r$ $(0<r<n)$, the VAR/VEC model should be used:

where:

$$
A(L) \Delta z_{t}=-\alpha \beta_{i} z_{t-1}+\varepsilon_{t}
$$

$$
\begin{gathered}
A(L) \text { - a polynomial matrix of rank } k ; \\
\alpha, \beta \text { - matrices of dimension } n \times r ; \\
z_{t}=\left(y_{t}, s_{t}\right) \text { - a vector of endogenous variables; } \\
\varepsilon_{i} \text { - a vector of stochastic shocks. }
\end{gathered}
$$

In accordance with the Granger test and 2SLS estimates, our assumption is that the number of students is affected by innovations to output contemporaneously, but innovations in education do not influence the industrial production/GDP, with a two-way causality between both endogenous variables observed for future periods. Similar ordering is chosen by Pereira and Aubyn (2009), who argue that the economic benefits of better-educated workers appear with a lag while innovations in output may immediately affect the education sector through labour market conditions. 


\section{RESULTS AND DISCUSSION}

\section{SLS Estimates}

The 2SLS estimates for determinants of output growth and student enrolment appear in Tables 5-6. As indicated by the coefficient of determination $\mathrm{R}^{2}$, independent variables explain $73-86 \%$ of changes in industrial production and $32-96 \%$ of changes in GDP. The explanatory power is higher for the number of students, as the $\mathrm{R}^{2}$ coefficient here is above $90 \%$. For all specifications, the ADF test reports stationarity of residuals.

Estimates for a specification with industrial production reveal a positive educational effect in levels and first differences, with a three-year lag (Table 4). Estimates for samples of 1992-2016 and 2000-2016 are rather similar, which implies a stability of educational effects over time. The same positive effect of the students' number is obtained in a specification with the GDP, but this time the coefficients for $\Delta s_{t-3}$ and $s_{t-3}$ are much smaller for a shorter sample of 2000-2016 (Table 5). Compared with earlier results by Shevchuk and Zyra (2012), this specification confirms a positive effect of the educational variable in levels while its effect in first differences becomes much more favourable.

Table 5. Determinants of industrial production and student enrolment in Poland in 1992-2017

\begin{tabular}{|l|c|c|c|c|}
\hline \multirow{2}{*}{ Variable } & \multicolumn{2}{|c|}{ Dependent variable $\Delta$ ind $_{\boldsymbol{t}}$} & \multicolumn{2}{c|}{ Dependent variable $\Delta \boldsymbol{s}_{\boldsymbol{t}}$} \\
\cline { 2 - 5 } & $\mathbf{1 9 9 2 - 2 0 1 7}$ & $\mathbf{2 0 0 0 - 0 1 7}$ & $\mathbf{1 9 9 2 - 2 0 1 7}$ & $\mathbf{2 0 0 0 - 2 0 1 7}$ \\
\hline$\Delta i n d_{t}$ & - & - & $-0.196\left(-5.11^{* * *}\right)$ & $-0.271\left(-4.34^{* * *}\right)$ \\
\hline$\Delta i n d_{t-1}$ & $-0.688\left(-6.44^{* * *}\right)$ & $0.027(0.19)$ & $-0.051\left(-1.86^{*}\right)$ & $0.022(0.49)$ \\
\hline$\Delta s_{t-1}$ & - & - & $0.894\left(34.73^{* * *}\right)$ & $0.935\left(21.56^{* * *}\right)$ \\
\hline$\Delta s_{t-3}$ & $-0.723\left(-2.19^{* *}\right)$ & $0.118\left(1.90^{*}\right)$ & - & - \\
\hline$s_{t-3}$ & $0.022\left(2.36^{* *}\right)$ & $0.010\left(6.45^{* * *}\right)$ & - & - \\
\hline$\Delta$ labour & $-1.396\left(-1.63^{*}\right)$ & $-0.610\left(-1.93^{*}\right)$ & - & - \\
\hline$\Delta i n v_{t}$ & $0.389\left(2.80^{* * *}\right)$ & $0.409\left(9.46^{* * *}\right)$ & $0.107\left(3.79^{* * *}\right)$ & $0.148\left(4.51^{* * *}\right)$ \\
\hline $\mathrm{R}^{2}$ & 0.24 & 0.79 & 0.96 & 0.95 \\
\hline $\mathrm{ADF}$ & $-4.10^{* * *}$ & $-5.37^{* * *}$ & $-4.69^{* * *}$ & $-3.67^{* * *}$ \\
\hline
\end{tabular}

Source: own calculations in EViews 10 (2017).

Regardless of the sample, an increase in industrial production is associated with lower student enrolment, while this is the case with GDP specification only for the 2000-2016 sample. Our results contrast with international studies that imply a positive correlation between industry and student enrolment, for example, Teixeira and Queiros (2016). However, a strong positive link between investments in physical capital and the number of students has been established over the period of 2000-2016. It may mean that the demand for higher education is created not so much by economic growth per se as by investment-driven innovations.

The lagged coefficient on $\Delta i n d_{t-1}$ becomes statistically insignificant in the estimates for the shorter 2000-2016 sample, while the statistically significant autoregressive coefficient on $\Delta y_{t-1}$ changes its sign. As for GDP, a strong impact of the past growth on the current growth rate has been established over the recent time span. Industrial production still lacks this favourable feature. Another difference between estimates for industrial production and 
GDP is that a stimulating effect on the GDP growth by investments in physical capital becomes significantly weaker in the 2000-2016 sample, while it is slightly stronger with respect to the industrial production growth. Such an outcome can be explained by the rapid expansion of the service sector, but it is questionable whether it would be possible to keep a sufficiently high GDP growth rate with substantially weaker human capital and physical capital effects, at least according to the 2SLS estimates. It is common for both regression specifications that employment does not influence economic growth, regardless of the data sample length. Such a feature emphasizes the lack of opportunities for extensive economic growth based upon a larger labour stock while strengthening arguments for human capital accumulation and better innovativeness (Table 6).

Table 6. Determinants of GDP and student enrolment in Poland in 1992-2017

\begin{tabular}{|l|c|c|c|c|}
\hline \multirow{2}{*}{ Variable } & \multicolumn{2}{|c|}{ Dependent variable $\Delta \boldsymbol{y}_{\boldsymbol{t}}$} & \multicolumn{2}{c|}{ Dependent variable $\Delta \boldsymbol{s}_{\boldsymbol{t}}$} \\
\cline { 2 - 5 } & $\mathbf{1 9 9 2 - 2 0 1 7}$ & $\mathbf{2 0 0 0 - 2 0 1 7}$ & $\mathbf{1 9 9 2 - 2 0 1 7}$ & $\mathbf{2 0 0 0 - 2 0 1 7}$ \\
\hline$\Delta \mathrm{y}_{t}$ & - & - & $-0.349(-1.34)$ & $-0.472\left(-1.99^{*}\right)$ \\
\hline$\Delta \mathrm{y}_{t-1}$ & $0.202\left(1.98^{*}\right)$ & $0.213\left(1.70^{*}\right)$ & $0.085(0.40)$ & $0.196(0.94)$ \\
\hline$\Delta s_{t-1}$ & - & - & $0.958\left(26.06^{* * *}\right)$ & $0.869\left(10.74^{* * *}\right)$ \\
\hline$\Delta s_{t-3}$ & $0.048\left(2.18^{* *}\right)$ & $0.034(1.17)$ & - & - \\
\hline$s_{t-3}$ & $0.007\left(6.77^{* * *}\right)$ & $0.007\left(5.78^{* * *}\right)$ & - & - \\
\hline$\Delta$ labour $r_{t}$ & $0.058(0.64)$ & $0.039(0.33)$ & - & - \\
\hline$\Delta$ inv $v_{t}$ & $0.116\left(8.87^{* * *}\right)$ & $0.117\left(7.75^{* * *}\right)$ & $0.107\left(2.83^{* *}\right)$ & $0.099\left(2.58^{* *}\right)$ \\
\hline $\mathrm{R}^{2}$ & 0.82 & 0.77 & 0.82 & 0.94 \\
\hline $\mathrm{ADF}$ & $-4.78^{* * *}$ & $-4.85^{* * *}$ & $-4.47^{* * *}$ & $-3.43^{* *}$ \\
\hline
\end{tabular}

Source: own calculations in EViews 10 (2017).

\section{VAR/VEC Estimates}

The cointegration coefficients imply a positive and stable long-term relationship for output (Table 7). Long-term coefficients do not reveal any differences across samples for the VAR/VEC model with industrial production. The estimated coefficient is of the same magnitude for the VAR/VEC model with GDP in the shorter 2000-2017 sample, but it is much smaller for the longer 1992-2017 sample.

Figure 3 presents the impulse response function of output to a one standard deviation shock in the number of students. Similar to long-term coefficients (Table 7), impulse response functions do not differ much across specifications and data samples. Except for the short-term response of ind $t$ to $s_{t}$, the higher student enrolment initially leads to a drop in industrial production followed by an increase in industrial output in the long term. If compared with the 2SLS estimates, the VAR/VEC estimates imply only a slightly weaker positive educational effect on GDP in 2000-2016, while outcomes seem to be somewhat asymmetrical for the specification with industrial production. Responses of ind $t$ and $y_{t}$ to innovations in $s_{t}$ in our estimates for Poland are very similar to those obtained by Oancea, Pospíšil, and Drăgoescu (2017) for the Czech Republic, although a short-lived negative effect on impact is somewhat similar to estimates for Romania. 
Table 7. VAR/VEC estimates of the long-term coefficients of educational effect on output in 1992-2017

\begin{tabular}{|c|c|c|c|c|}
\hline \multirow{2}{*}{ Coefficient } & \multicolumn{2}{|c|}{ Specification with ind $_{\boldsymbol{t}}$ and $\boldsymbol{s}_{\boldsymbol{t}}$} & \multicolumn{2}{c|}{ Specification with $\boldsymbol{y}_{\boldsymbol{t}}$ and $\boldsymbol{s}_{\boldsymbol{t}}$} \\
\cline { 2 - 5 } & $\mathbf{1 9 9 2 - 2 0 1 7}$ & $\mathbf{2 0 0 0 - 2 0 1 7}$ & $\mathbf{1 9 9 2 - 2 0 1 7}$ & $\mathbf{2 0 0 0 - 2 0 1 7}$ \\
\hline The coefficient on $s_{\boldsymbol{t}}$ & $1.456(0.08)$ & $1.545(0.11)$ & $0.452(0.15)$ & $1.417(0.11)$ \\
\hline
\end{tabular}

Note: standard deviation in brackets.

Source: own calculations in EViews 10 (2017).

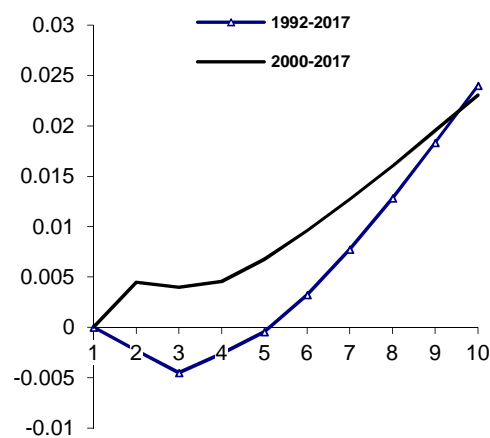

a) industrial production

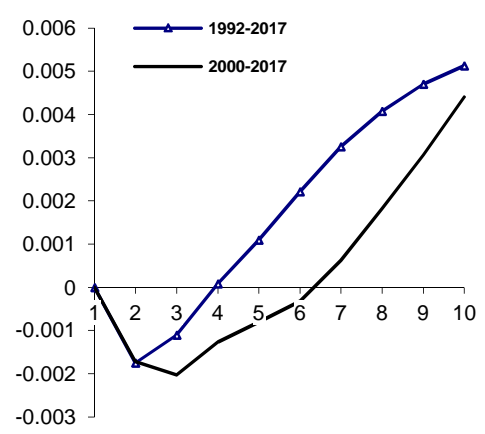

b) GDP

Figure 3. The impulse response function of output to the number of students output in Poland in 1992-2017 Source: own calculations in EViews 10 (2017).

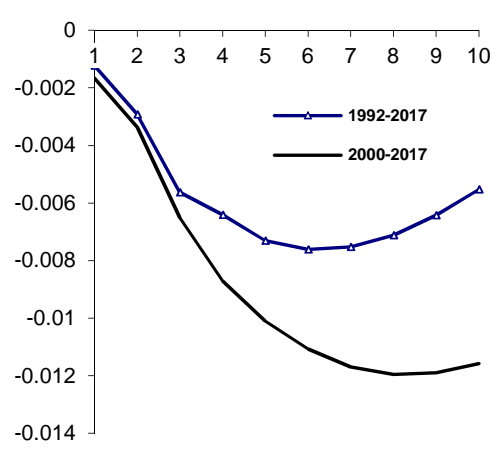

a) industrial production

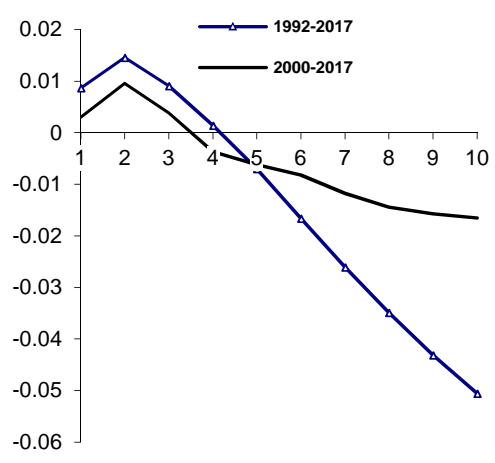

b) GDP

Figure 4. The impulse response function of the number of students to output in Poland in 1992-2017 Source: own calculations in EViews 10 (2017).

Following the argument of Otsuka et al. (2017), among others, a growing role of higher education in the 2000-2017 period in respect to industrial production in the VAR/VEC estimates could indicate the ability to better utilise the existing technology gap. On the other hand, the weakening of higher education's impact on GDP in 2000- 
2017 seems to contradict the assumption that positive human capital effects gain in agreement with the increase of income, as argued by Benhabib and Spiegel (1994). If we consider educational effects on industrial production, a decrease in the number of students since the middle of the 2000s provides some credibility to the argument by Krueger and Lindahl (2001) that education effects are higher in the economies with low levels of education. Moreover, this observation does not contradict Marconi's (2018) findings on the long-term nature of higher education.

Similar to 2SLS estimates, there appears a clear negative relationship between industrial production and the number of students, with no significant differences across data samples (Figure 4). However, impulse response functions are quite different with respect to the short-term reaction of student enrolment to GDP. As estimates for both samples imply, an increase in GDP produces an inverted U-shape response function: following an increase in the GDP, student enrolment increases on impact but then falls below the initial level over a decade. Fortunately, we may argue that the causality running from output to student enrolment weakened over the last few years; a positive feature that is likely to only gain in strength by an investment-driven demand for higher education, as reported by the 2SLS estimates.

Table 8. The forecast error variance decomposition of the number of students and output in Poland in 1992-2017 (in \%)

\begin{tabular}{|l|l|r|r|r|r|r|r|}
\hline \multirow{2}{*}{ Response of } & \multirow{2}{*}{ Sample } & \multicolumn{7}{|c|}{ Forecast horizons } \\
\cline { 3 - 8 } & & $\mathbf{1}$ & $\mathbf{2}$ & $\mathbf{3}$ & $\mathbf{5}$ & $\mathbf{7}$ & \multicolumn{1}{c|}{$\mathbf{1 0}$} \\
\hline \multirow{2}{*}{ ind $t_{t}$ to innovations in $s_{t}$} & $1992-2017$ & 0 & 0 & 1 & 1 & 2 & 24 \\
\cline { 2 - 8 } & $2000-2017$ & 0 & 4 & 6 & 11 & 28 & 60 \\
\hline \multirow{2}{*}{$y_{t}$ to innovations in $s_{t}$} & $1992-2017$ & 0 & 0 & 0 & 0 & 1 & 2 \\
\cline { 2 - 8 } & $2000-2017$ & 0 & 0 & 1 & 1 & 1 & 2 \\
\hline \multirow{2}{*}{$s_{t}$ to innovations in ind $t$} & $1992-2017$ & 1 & 1 & 2 & 2 & 2 & 1 \\
\cline { 2 - 8 } & $2000-2017$ & 2 & 2 & 3 & 4 & 4 & 4 \\
\hline \multirow{2}{*}{$s_{t}$ to innovations in $y_{t}$} & $1992-2017$ & 30 & 30 & 17 & 6 & 9 & 17 \\
\cline { 2 - 8 } & $2000-2017$ & 13 & 26 & 14 & 6 & 6 & 9 \\
\hline
\end{tabular}

Source: own calculations in EViews 10 (2017).

Regardless of the sample, the analysis of the forecast error variance decomposition (FEVD) supports the marginal role of the educational variable in the changes in GDP (Table 8). On the other hand, the number of students seems to be an important factor behind the developments in the industry, with the fraction of $s_{t}$ in FEVD of ind th $_{t}$ at the maximum of $24 \%$ in the $1992-2017$ sample and even $60 \%$ in the shorter $2000-2017$ sample. While the causality running from $s_{t}$ to $y_{t}$ is weak, innovations in GDP are a very important factor supporting student enrolment, with the fraction of $y_{t}$ in FEVD of $s_{t}$ gradually declining from $30 \%$ to $6 \%$ and from $26 \%$ to $6 \%$ in estimates for the $1992-2017$ and the $2000-2017$ sample, respectively. Industrial output simultaneously does not exert any significant impact on the number of students. This fact means that the pattern of favourable causality running from industrial production to student enrolment - as shown by the impulse response function (Fig. 4a) - signifies potential correlation that is yet to be realized. 


\section{CONCLUSIONS}

Empirical results reveal that there is a very robust causal relationship between the number of students and output in Poland, especially in the industrial sector. In this context, a significant decrease in the number of students - almost by a third since the middle of the 2000s - cannot but raise serious concerns. Both 2SLS and VAR/VEC estimates are in firm support of the stock version (the Nelson-Phelps approach) of the higher education effects on output, while the evidence of the investment version (neoclassical model) are ambiguous. For an economy at risk of the middle-income trap, unpleasant long-term effects of insufficient human capital stock are especially worrisome. As there is a decrease in the number of students in response to both industrial production and GDP growth except for the latter effects on impact (VAR/VEC estimates) - it is an argument in favour of discreet measures aimed at boosting student enrolment. Other findings indicate that investments in physical capital are significant factors behind output, with a strong positive impact on the number of students as well. The employment seems to have no influence on either output or student enrolment. However, this study does not account for business cycle properties of the labour market. Other research limitations are the lack of control for structural shifts and the inability to trace relationships at longer lags due to a relatively short annual time series.

I recommend that the feedback from industrial output to demand higher education should be strengthened with a focus on closer cooperation between industrial firms and universities. Admittedly, the relatively short sample of annual data does not allow for control of several important independent variables, such as output abroad, trade openness, capital flows, or unemployment rate. Moreover, further research should consider studying causal links between education and output with disaggregated data across fields of study in order to explain the likely mismatch between demand for university graduates and their supply.

\section{REFERENCES}

Abankina, I., \& Filatova, L. (2015). Sustaining Student Enrolment: Impact of Demand Trends for Higher Education in Russia. Journal of US-China Public Administration, 12(5), 345-359. https://doi.org/10.17265/1548-6591/2015.05.002

Asteriou, D., \& Agiomirgianakis, G. (2001). Human capital and economic growth: Time series evidence from Greece. Journal of Policy Modeling, 23(5), 481-489. https://doi.org/10.1016/S01618938(01)00054-0

Barcenilla-Visús, A., \& López-Pueyo, C. (2018). Inside Europe: human capital and economic growth revisited. Empirica, 45(4), 821-847. https://doi.org/10.1007/s10663-017-9394-2

Barro, R.J., \& Sala-i-Martin, X. (1995). Economic Growth. McGraw-Hill, New York.

Benhabib, J., \& Spiegel, M. (1994). The role of human capital in economic development: Evidence from aggregate cross-country data. Journal of Monetary Economics, 34(2), 143-173. https://doi.org/10.1016/0304-3932(94)90047-7

Bils, M., \& Klenow, P. (2000). Does schooling cause growth? American Economic Review, 90(5), 11601183. https://doi.org/10.1257/aer.90.5.1160

Benos, N., \& Zotou, S. (2014). Education and Economic Growth: A Meta-Regression Analysis. World Development, 64(C), 669-689. https://doi.org/10.1016/j.worlddev.2014.06.034 
Bhorat, H., Cassim, A., \& Tseng, D. (2016). Higher education, employment and economic growth: Exploring the interactions. Development Southern Africa, 33(3), 312-327. https://doi.org/ 10.1080/0376835X.2016.1161501

Boldin, R., Morote, E.S., \& McMullen, M. (1996). Higher Education and Economic Growth in Latin American Emerging Markets. Retrieved from lasa.international.pitt.edu/Lasa2000/ BoldinetalPDF.pdf on September 2, 2019.

Bulman, D., Eden, M., \& Nguen, H. (2017). Transitioning from low-income growth to high-income growth: Is there a middle-income trap?. Journal of the Asia Pacific Economy, 22(1), 5-28. https://doi.org/10.1080/13547860.2016.1261448

Cuaresma, J.C., Doppelhofer, G., Huber, F., \& Pitibauer, P. (2018). Human capital accumulation and long-term income growth projections for European regions. Journal of Regional Studies, 58(1), 81-99. https://doi.org/10.1111/jors.12339

Delgado, M., Henderson, D.J., \& Parmeter, C. (2014). Does Education Matter for Economic Growth?. Oxford Bulletin of Economics and Statistics, 76(3), 334-359. https://doi: 10.1111/obes.12025

De Meulemeester, J.-L., \& Rochat, D. (1995). A causality analysis of the link between higher education and economic development. Economics of Education Review, 14(4), 351-361. https://doi.org/10.1016/0272-7757(95)00015-C

Dragoescu, R.M. (2015). Education as a determinant of the economic growth. The case of Romania. Procedia - Social and Behavioral Sciences, 197, 404-412.

Eckstein, Z., Sarid, A., \& Tamir, Y. (2017). Cross Countries Aggregate Education Impact on GDP percapita: Growth or Levels?. The University of Haifa, Izrael.

EViews 10 (2017). EViews 10 User's Guide II. Irvine, CA: IHS Global Inc. Retrieved from https://www3.nd.edu/ nmark/FinancialEconometrics/EViews10_Manuals/

EViews\%2010\%20Users\%20Guide\%20II.pdf on August 29, 2019.

Fotea, A.C., \& Guțu, C. (2016). Historical and Theoretical Framework of the Relation between Higher Education Institutions and the Process of Regional Economic Development. Entrepreneurial Business and Economics Review, 4(1), 23-42. https://doi.org/10.15678/EBER.2016.040103

Gradzewicz, M., Growiec, J., Kolasa, M., Postek, L., \& Strzelecki, P. (2018). Poland's uninterrupted growth performance: new growth accounting evidence. Post-Communist Economies, 30(2), 238-272. https://doi.org/10.1080/14631377.2017.1398519

Hanushek, E.A., \& Woessmann, L. (2008). The role of cognitive skills in economic development. Journal of Economic Literature, 46(3), 607-668. https://doi.org/10.1257/jel.46.3.607

Hermannsson, K., Lisenkova, K., Lecca, P., McGregor, P., \& Kim, S.J. (2017). The external benefits of higher education. Regional Studies, 51(7), 1077-1088. https://doi.org/10.1080/00343404. 2016.1172062

Islam, N. (1995). Growth empirics: a panel data approach. Quarterly Journal of Economics, 110(4), 1127-1170. Retrieved from https://www.jstor.org/stable/2946651 on August 25, 2019.

Krueger A., \& Lindahl, M. (2001). Education for Growth: Why and For Whom?. Journal of Economic Literature, XXXIX(4), 1101-1136. https://doi.org/10.1257/jel.39.4.1101

Kot, S., \& Slusarczyk, B. (2014). Problems in the development of higher education in Poland. World Transactions on Engineering and Technology Education, 12(4), 675-680.

Lenkei, B., Mustafa, G., \& Vecchi, M. (2018). Growth in emerging economies: Is there a role for education?. Economic Modelling, 73, 240-253. https://doi.org/10.1016/j.econmod.2018.03.020

Lucas, R.E. (1988). On the mechanics of economic development. Journal of Monetary Economics, 22(1), 3-42. https://doi.org/10.1016/0304-3932(88)90168-7 
Mankiw, N.G., Romer, D., \& Weil, D.N. (1992). A contribution to the empirics of economic growth. Quarterly Journal of Economics, 107(2), 407-437. https://doi.org/10.2307/2118477

Madsen, J., \& Martin, F. (2017). British economic growth since 1270: the role of education. Journal of Economic Growth, 22, 229-272. https://doi.org/10.1007/s10887-017-9145-z

Marconi, G. (2018). Education as a Long-Term Investment: The Decisive Role of Age in the EducationGrowth Relationship. Kyklos, 71(1), 132-161.

Marklund, G., Naczinsky, C., Ziarko, W., Winckler, G., Puukka, J., File, J., Holm-Nielsen, L.B., \& Melin, G. (2017). Poland's Higher Education and Science System: Horizon 2020 Policy Support Facility. Luxembourg: Publications Office of the European Union. https://doi.org/10.2777/193011

Nelson, R.R., \& Phelps, E.S. (1966). Investment in humans, technological diffusion, and economic growth. American Economic Review, 56(1), 69-75.

Nowak. H. (2016). The Role of the Polish Higher Education System in the Development of Entrepreneurship. Entrepreneurial Business and Economics Review, 4(1), 43-59. https://doi.org/ 10.15678/EBER.2016.040104

Oancea, B., Pospíšil, R., \& Drăgoescu, R.M. (2017). Higher Education and Economic Growth: A Comparison Between the Czech Republic and Romania. Prague Economic Papers, 26(4), 467486. https://doi.org/10.18267/j.pep.622

Obradović, S., \& Lojanica, N. (2016). Higher Education and Economic Growth: Swedish Evidence From Multivariate Framework. Facta Universitatis, Series: Economics and Organization, 13(2), 177-185.

Otsuka, K., Higuchi, Y., \& Sonobe, T. (2017). Middle-income traps in East Asia: An inquiry into causes for slowdown in income growth. China Economic Review, 46, 3-16. https://doi.org/ 10.1016/j.chieco.2017.02.002

Pegkas, P., \& Tsamadias, C. (2014). Does Higher Education Affect Economic Growth?. The Case of Greece. International Economic Journal, 28(3), 425-444. https://doi.org/10.1080/ 10168737. 2014.894551

Pereira, J., \& Aubyn, M. (2009). What level of education matters most for growth? Evidence from Portugal. Economics of Education Review, 28(1), 67-73. https://doi.org/10.1016/ j.econedurev.2007.12.001

Petrakis, P.E., \& Stamatakis, D. (2002). Growth and educational levels: a comparative analysis. Economics of Education Review, 21(5), 513-521. https://doi.org/10.1016/S0272-7757(01)00050-4

Podrecca, E., \& Carmeci, G. (2002). Does Education Cause Economic Growth?. University of Triest, Italy.

Pritchett, L. (2001). Where has all the Education gone?. World Bank Economic Review, 15(3), 367-

391. https://doi.org/10.1093/wber/15.3.367

Romer, P.M. (1990). Endogenous technological change. Journal of Political Economy, 98(5), 71-102. https://doi.org/10.1086/261725.

Schofer, E., \& Meyer, J. (2005). The Worldwide Expansion of Higher Education in the Twentieth Century. American Sociological Review, 70(6), 898-920.

Simionescu, M., Lazányi, K., Sopková G., Dobeš, K., \& Balcerzak, A. (2017). Determinants of Economic Growth in V4 Countries and Romania. Journal of Competitiveness, 9(1), 103-116. https://doi.org/ 10.7441/joc.2017.01.07

Shevchuk, V., \& Zyra, J. (2012). Education for Growth: The Polish Experience. In J. Pociecha (Ed.), Methods and Models for Analysing and Forecasting Economic Processes (pp. 11-31). Cracow: Cracow University of Economics.

Su, D., \& Yao, Y. (2016). Manufacturing as the key engine of economic growth for middle-income economies. ADBI Working Paper Series, 573. 
Teixeira, A., \& Queirós, A. (2016). Economic growth, human capital and structural change: A dynamic panel data analysis. Research Policy, 45(8), 1636-1648. https://doi.org/10.1016/j.respol. 2016.04.006

Windolf, P. (1992). Cycles of expansion in higher education 1870-1985: an international comparison. Higher Education, 23(1), 3-19. https://doi.org/10.1007/BF00141141

Yardimcioğlu, F., Gürdal, T., \& Itundemir, M.E. (2014). Education and Economic Growth: A Panel Cointegration Approach in OECD Countries (1980-2008). Egitim ve Bilim, 39(173), 1-12.

Vandenbussche, J., Aghion, P., \& Meghir, C. (2006). Growth, distance to frontier and composition of human capital. Journal of Economic Growth, 11(2), 97-127. https://doi.org/10.1007/s10887006-9002-y

Zaremba, M. (2018). Problem pułapki średniego dochodu - perspektywa polska. Nierówności Społeczne a Wzrost Gospodarczy, 3(55), 243-256. https://doi.org/10.15584/nsawg.2018.3.16

\section{Author}

\section{Joanna Żyra}

Associate Professor at the Cracow University of Technology. Her main research interests include economics of education, determinants of innovation-based regional growth, and project management.

Correspondence to: Prof. Joanna Zyra, PhD, Cracow University of Technology, Cracow, ul. Warszawska 24, Poland, e-mail: jzyra@pk.edu.pl

ORCID (1) http://orcid.org/0000-0003-1562-5639

\section{Acknowledgements and Financial Disclosure}

The authors would like to thank anonymous referees for their useful comments, which allowed to increase the value of this article.

\section{Copyright and License}

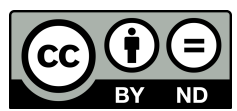

This article is published under the terms of the Creative Commons

Attribution - NoDerivs (CC BY-ND 4.0) License

http://creativecommons.org/licenses/by-nd/4.0/

\section{Published by the Centre for Strategic and International Entrepreneurship - Krakow, Poland}

